\title{
Influence of Investors' Preference towards SBI Mutual Fund in Chennai City
}

\author{
M. Rajesh
}

\begin{abstract}
In India, the savings from individual households contribute a large share in the capital appreciation. There are various ways such as purchase of real assets, Shares, stocks and securities in which the savings can be invested. Mutual Funds play a predominant role in collecting the funds from small investors and invest in balanced portfolio of securities. Investors have completely different outlook while they choose of investing in a specific avenue. The primary objective of investor is to safeguard his saving in safer and liquid investment opportunity taking into account his anticipation and his risk tolerance capacity. Hence, an attempt is made to identify the preferential attitude of investors and its influence on SBI mutual fund schemes taking into account social economic individual saving habit, social, economic, individual savings pattern and the level of confidence on investment schemes.
\end{abstract}

Keywords : Risk appetite, liquidity, Return on investment, Asset Management Company.

\section{INTRODUCTION}

A monetary markets become are complex, capitalist would like a monetary mediator who will offer the specified information and skilled experience in making privy choices. Mutual funds act as this liaison. Persons from every walk of life are investing their money in one way or the other. The volume and composition of savings are very important for a developing nation. In India, the savings from individual households contribute a large share in the national savings. There are various ways in which the savings can be channelized effectively to increase the capital appreciation and attaining a better return.

The investors are in a dilemma while selecting the investment options. It is understood that there is a need to conduct a research work in the area of investment pattern and suggesting ways to help them in selecting a better avenue in the future.

A comprehensive regulatory framework for the MF business was provided by The SEBI that was established in 1996 for supervising and controlling the financial transactions of capital markets in India. This has positively impacted by opening of Mutual Fund organizations in different sector our country. Average Assets Under Management of Indian MF Industry for the month of July 2019 is calculated as Rs.25,81,026 crore. The Mutual Fund Industry's AUM has grown from Rs. 10.06 trillion as on 31st

Revised Manuscript Received on December 05, 2019.

* Correspondence Author

Dr. M. Rajesh*, Assistant Professor, A.M. Jain College, Chennai, Tamilnadu, India Email ID: drmrajesh123@gmail.com

July, 2014 to Rs.24.54 trillion as on 31st July, 2019, about 2.5 times increase during a period of the last 5 years. Today, the Indian Mutual fund business has paved the way for exciting investment opportunities for investors and perhaps one of the most favorite investment options for small and medium sized investors.

\section{REVIEW OF LITERATURE:}

A study conducted by Manjunath S.A.(2015) revealed the investors' prototype towards different Mutual Fund Schemes and the wakefulness of middle class ,salaried investors in selecting a proper mix of debt and equity. These type of investors have tried multiple possibility of investment and decided their saving model. The socio economic variables such as age, gender, income, education, family background, economical framework and occupation had been found to have influenced the investors towards a selective kind of investment and had a significant impact.

According to Nikhil Agarwal (2014), an ideal investor will prefer to decide his pattern of investing in mutual funds based on critical factors such as understanding of the current scenario of financial markets, availability of time, risk appetite or risk tolerance level, return expected by the investors, thereby balancing between risk and return on investment. The investors are carefully planning their net worth by considering the liquidity, profitability and durability of their investment in appropriate mutual fund schemes.

V.Rathnamani (2013) identified the factors such as Risk, Return, Safety and liquidity are contributing to the preferential treatment given by investors to invest in mutual fund in attaining greater return at lower risk level and ensuring liquidity in terms of realizing the proceeds. He also recognized the importance of Mutual Fund as an investment vehicle in focusing the notice difference strata $\mathrm{He}$ has also studied the method of investment preferred by the investors in Mathura.

\section{STATEMENT OF THE PROBLEM}

The capitalist are in a dilemma while selecting the investment options such as Gold, Bonds, Shares, debentures, Deposit Schemes, etc., It is understood that there is a need to conduct a research work in the area of investment pattern and suggesting ways to people to help them invest in a better avenue in the future. 


\section{SCOPE OF STUDY}

The study is confined to the capitalist preference towards ETF schemes, The study is covering the essential variables required for analysis and interpretation such as demographic factors, preferential factors and types of mutual fund schemes. The study encompass salaried private and public sector investors, businessmen and small investors in and around the chennai city.

\section{OBJECTIVE OF THE STUDY}

- To catch on the preferential factors of the investors for asset management company.

- To identify the persuade investors to invest in SBI mutual funds and know the preference of the portfolio.

\section{A. Hypothesis of the Study}

1. There is no relationship between preferential treatment of the investors and their interest in SBI Mutual Fund.

2. The impress investment in Mutual Funds doesn't impact the preference of portfolio in mutual funds.

\section{LIMITATION OF THE STUDY}

1. This research work applicable to Chennai city

2. This work based on perception oriented subject to change day to day life.

\section{RESEARCH METHADOLOGY}

The present study used both raw data and published data. Raw data have been collected 109 respondents in and around Chennai city. Secondary data collected from magazines, newspapers, articles, books, thesis, and websites etc., SPSS tools such as X2 test and ANOVA used.

\section{A. Sample Size}

A framed question sheet was prepared to collect the responses from the investors selected in and around Chennai. The sample size for the research was 109 .

\section{DATA ANALYSIS}

Table 1: Crosstab between features attracting investors and interest in mutual funds

\begin{tabular}{|c|c|c|c|c|}
\hline \multicolumn{2}{|c|}{ Particulars } & \multicolumn{2}{|c|}{$\begin{array}{c}\text { Investment } \\
\text { in MF }\end{array}$} & \multirow{2}{*}{ Total } \\
\cline { 2 - 4 } \multicolumn{1}{|c|}{} & No & Yes & \\
\hline & Diversification & 4 & 18 & 22 \\
FUTURE & Better rate of return & 9 & 15 & 24 \\
ATTRACTS & Regular income & 5 & 13 & 18 \\
& Tax benefit & 6 & 26 & 32 \\
& Less Risk \& Transaction cost & 13 & 0 & 13 \\
& Total & 37 & 72 & 109 \\
\hline
\end{tabular}

Source: computed data

It is inferred that 72 respondents are interested in mutual fund investment and 37 respondents are not interested in invest mutual fund. It can be understood that majority respondents are selecting mutual fund for tax benefit purpose. SBI Mutual Fund schemes like equity, debt, hybrid, liquid,

Table 2: Chi square tests

\begin{tabular}{|c|c|c|c|}
\hline & Value & Df & $\begin{array}{c}\text { Asymp. Sig. } \\
\text { (2-sided) }\end{array}$ \\
\hline Pearson Chi-Square & $31.471 \mathrm{a}$ & 4 & .000 \\
\hline Likelihood Ratio & 34.894 & 4 & .000 \\
\hline Linear-by-Linear Association & 7.664 & 1 & .006 \\
\hline N of Valid Cases & 109 & & \\
\hline
\end{tabular}

Source: computed Data

As the value of $\mathrm{p}$ is 0.00 the $\mathrm{H}$ o is summarily rejected and a strong association found between characteristics attracting investors like diversification, better return on investment, standard income, tax advantage, lesser risk \& operation cost and their interest in selecting Mutual Funds schemes of SBI.

Table 3: Chi-Square Tests of Safety of Investment and Interest in Mutual Funds

\begin{tabular}{|c|c|c|c|c|c|}
\hline & Value & Df & $\begin{array}{c}\text { Asymp. } \\
\text { Sig. } \\
\text { (2-sided) }\end{array}$ & $\begin{array}{c}\text { Exact Sig. } \\
\text { (2-sided) }\end{array}$ & $\begin{array}{c}\text { Exact Sig. } \\
\text { (1-sided) }\end{array}$ \\
\hline Pearson Chi-Square & $14.409 \mathrm{a}$ & 1 & .000 & & \\
\hline $\begin{array}{c}\text { Continuity } \\
\text { Correctionb }\end{array}$ & 12.560 & 1 & .000 & & \\
\hline Likelihood Ratio & 13.753 & 1 & .000 & & .000 \\
\hline Fisher's Exact Test & & & & & .000 \\
\hline $\begin{array}{c}\text { Linear-by-Linear } \\
\text { Association }\end{array}$ & 14.277 & 1 & .000 & & \\
\hline N of Valid Cases & 109 & & & & \\
\hline
\end{tabular}

Source: computed Data

The table reflects that the $\mathrm{X} 2$ value $14.409, \mathrm{p}=$ 0.000 .hence, the strong connection Safety of investment and their interest in s Mutual Funds.

Table 4:Chi-Square Tests of Higher Return and Interest in Mutual Funds

\begin{tabular}{|c|c|c|c|c|c|}
\hline & Value & Df & $\begin{array}{c}\text { Asymp. } \\
\text { Sig. } \\
(2 \text {-sided })\end{array}$ & $\begin{array}{c}\text { Exact Sig. } \\
(2 \text {-sided })\end{array}$ & $\begin{array}{c}\text { Exact Sig. } \\
(1 \text {-sided })\end{array}$ \\
\hline Pearson Chi-Square & $6.439 \mathrm{a}$ & 1 & .011 & & \\
\hline $\begin{array}{c}\text { Continuity } \\
\text { Correctionb }\end{array}$ & 4.904 & 1 & .027 & & \\
\hline Likelihood Ratio & 6.052 & 1 & .014 & & .020 \\
\hline Fisher's Exact Test & & & & & .015 \\
\hline $\begin{array}{c}\text { Linear-by-Linear } \\
\text { Association }\end{array}$ & 6.380 & 1 & .012 & & \\
\hline N of Valid Cases & 109 & & & & \\
\hline
\end{tabular}

Source: computed Data

The table exhibits that $\mathrm{X} 2$ value $6.439, \mathrm{p}=0.011$. Therefore it is found that the strong relationship between Higher Return on investment and their interest in selecting Mutual Funds. It can be concluded that majority respondents are select mutual based on higher return on investment.

Table: 5: ANOVA of factors influencing investment in Mutual Funds \& Preference of Portfolio

\begin{tabular}{|c|c|c|c|c|c|}
\hline & $\begin{array}{c}\text { Sum of } \\
\text { Squares }\end{array}$ & Df & $\begin{array}{c}\text { Mean } \\
\text { Square }\end{array}$ & F & Sig. \\
\hline Between Groups & 7.177 & 5 & 1.435 & 7.138 & .000 \\
\hline Within Groups & 20.713 & 103 & .201 & & \\
\hline Total & 27.890 & 108 & & & \\
\hline
\end{tabular}

Source: Primary Data

It is referred $F$ value 7.138, p value is $=0.000$ at $5 \%$ level. Therefore there is a strong influence of factors motivating investors and their preference towards Portfolio of Investments.

Table 6: ANOVA between Performance of SBI and 
Satisfaction level of Investors

\begin{tabular}{|c|c|c|c|c|c|c|}
\hline & \multicolumn{2}{|c|}{ Cluster } & \multicolumn{2}{c|}{ Error } & \multirow{2}{*}{ F } & \multirow{2}{*}{ Sig. } \\
\cline { 2 - 6 } & $\begin{array}{c}\text { Mean } \\
\text { Square }\end{array}$ & Df & $\begin{array}{c}\text { Mean } \\
\text { Square }\end{array}$ & Df & & \\
\hline SATISFIEDBYSBIMF & 32.803 & 1 & .513 & 107 & 63.973 & .000 \\
\hline PERFORMANCE & 74.650 & 1 & .193 & 107 & 387.454 & .000 \\
\hline
\end{tabular}

Source: computed Data

The above table of ANOVA exhibits statistically significant at 5\% level $\mathrm{F}$ Value $=63.973, \mathrm{p}$ Value $=0.000$. Therefore it can be concluded that positive association between Satisfaction of SBI Mutual Funds investors and their performance level.

\section{FINDINGS}

- It is observed that in recent trends, the respondents whose income falling in the range of 2,50,000 to 5,00,000 are want to secure their future by investing in SBI Mutual Fund Investments.

- Many of them are choose to invest for the purpose of getting tax benefits. From the data pertaining to the channel of investment, majority of respondents $(71 \%)$ choose to invest through Bankers and sub-brokers for proper guidance and direction.

- $46 \%$ of respondents are in one time investment and 54\% of the respondents are in systematic investment plan. Many investors (74\%) are chosen their investment pattern with the combination of debt and equity portfolio.

\section{SUGGESTIONS}

$>$ The Fund advisors should focus on young investors for increasing the investment into SBI Mutual fund Schemes by sharing their expertise on this industry.

$>$ The risk bearing level of the investors/customers, their need and time duration of investment is to be well noted by Financial Advisor before making any commitment to Mutual Fund investment.

$>$ A well organized induction programme to be arranged for the individual Financial Advisor about the Fund/Scheme and its objective, as they play a important role in impress in the investors.

$>$ The present trend lock-in-period of 3 years can be reduced to 2 years or less for better liquidity and portability from one scheme to another from the view point of investor' $\mathrm{s}$.

\section{CONCLUSION}

The investor has to follow the necessary steps for investing in Mutual funds such as identifying investment needs, Start early investing in mutual fund, get in touch with advisors or AMC agencies, choosing the right mutual fund, Selecting the ideal mix of schemes, Investing regularly, Keeping the taxation aspect in mind, As far as SBI Mutual Funds are concerned, the investors are feeling a safe and profitable by opting a combination of Debt and Equity portfolio to strike a balance between Return and Risk.

\section{REFERENCES}

1. "Market sentiments and trends in growth of mutual fund schemes: An insight into Indian mutual industry" by Bhargava Rashmi, Assistant Professor DAV Institute of Management NIT, Faridabad, India.

2. "Investor's preference towards mutual fund in comparison to other investment avenues"- Gaurav Agrawal, Research scholar at Mewar University, Chittorgarh, Rajasthan.and Dr. Mini Jain, Assistant Professor at R.C.A. (PG) Girls Degree College, Mathura, U.P., India

3. "A Study of Fund Selection Behaviour of Individual Investors towards Mutual Funds - with Reference to Mumbai City"- Ranganathan and Kavitha.Indian Institute of Capital Markets, 9th Capital Markets Conference Paper.

4. V.Rathnamani(2013), Investors preference towards mutual fund industry in trichy, IOSR JBM, Vollume 6, issue 6, (Jan - Feb 13) pp 48 -55.

5. Vidya Shankar S (1990), Mutual funds, Emerging trends in India, chartered secretary, Volume 20(8) 639-640.

\section{AUTHOR PROFILE}

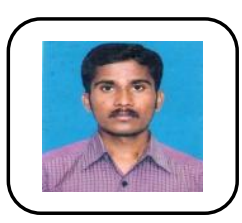

Dr. M. Rajesh, is an Assistant professor in the Department of commerce, A.M.Jain College, University of Madras, Chennai, Tamilnadu, India. He is 1st Rank Holder both UG \& PG and has 7 years teaching experience. His Area of interest is Finance and marketing. He has presented research paper in various international and national level conferences and also published research paper in various reputed journal. 